\title{
Van registratienummer tot gelijkwaardige gesprekspartner
}

\author{
De evaluatie van de positie der kleinere kantoren binnen het NIVRA
}

Dis. M.J.J.M. van Grootel

\section{Inleiding}

De 'kleinere kantoren' hebben zich als groep, met name de laatste jaren, ontwikkeld van kantoren, die in belangrijke mate zelfstandig opereerden en een grote afstand hadden tot de NIVRAorganisatie, tot een groep met een groot aantal samenwerkingsverbanden en een belangrijke rol als gesprekspartner van en participant in de activiteiten van het NIVRA.

Als kleinere kantoren worden hierbij die kantoren aangemerkt waaraan ten hoogste tien registeraccountants zijn verbonden.

De achtergronden voor het inzetten van deze ontwikkeling en de wijze waarop dit bij een van de grotere samenwerkingsverbanden werd uitgewerkt wordt in het navolgende verder toegelicht.

\section{Ontwikkeling van de groep 'kleinere accountantskantoren'}

Van een specifieke ontwikkeling van de 'kleinere accountantskantoren', binnen het honderdjarig bestaan van het NIVRA, uitmondend in een eigen structuur en met een eigen problematiek, is eigenlijk pas sprake vanaf het begin van de jaren zestig.

In deze periode ontstaan zeer grote organisatorisch eenheden, waarbinnen het accountantsberoep wordt uitgeoefend.

Deze grote eenheden blijken door hun omvang zeer wel in staat, tijd en ruimte vrij te maken, om vakkennis en vaktechniek op peil te houden en te verbeteren.

Daarnaası waren zij door hun omvang ook beter in staat om grote en zeer grote opdrachten naar zich toe te halen.

Hun betrokkenheid bij grote ondernemingen, die veelal 'internationaal gingen', bracht voor deze grote eenheden ook verbanden in de internationale sfeer tot stand, hetgeen ook een bepalende invloed op de structuur van deze eenheden had.

Aan de andere kant leidde de structuur van deze grote eenheden tot een grote mate van specialisatie ten aanzien van de uit te voeren werkzaamheden.

Bindenga ${ }^{1}$ vermeldt hieromtrent het ontstaan van een hiërarchie binnen de van oorsprong 'platte' organisaties van beroepsbeoefenaren en concludeert dat de grote kantoren in feite ondernemingen zijn, die worden beheerst door het streven naar continuïteit.

De structuur van de kleinere kantoren was in deze periode duidelijk een andere; geen specialisatie maar een zeer brede adviesfunctie gekoppeld aan de attestfunctie, weinig ruimte voor uitbouw vaktechniek en weinig internationale activiteiten.

Het kleinere kantoor was daarnaast in belangrijke mate op midden- en kleinbedrijf gericht.

Door hun omvang drukten de grote organisaties uiteraard een belangrijk stempel op de NIVRA-organisatie en was de betrokkenheid van de kleinere kantoren veelal beperkt tot de inschrijving in het register en het jaarlijks betalen van de contributie met als ongewenst bijverschijnsel de indruk, dat het NIVRA-bestuur zich te weinig

Drs. M. van Grootel RA studeerde economie aan de Katholieke Universiteit Brabant (hoofdvak bedrijfseconomie). Doctoraal examen in 1970, RA-titel in 1973 en is oud bestuurslid NIVRA, oud-voorzitter stuurgroep kleine kantoren en oud voorzitter SRA, thans bestuurslid SRA. Sedert 1975 verbonden aan en thans vennoot bij de Foederer Groep te Eindhoven. 
bekommerde om de specifieke problemen van de kleinere kantoren.

Problemen. die zich op allerlei gebieden voordeden, zowel op vaktechnisch als niet vaktechnisch gebied.

Door de snelle ontwikkelingen op vaktechnisch gebied mede onder invloed van de vaktechnische afdelingen van de grote organisaties, dreigden de kleinere kintoren achterstand op te lopen.

Ook werd de indruk gewekt dat belangrijke beslissingen buiten de kleinere kantoren om werden genomen. mede door hun geringe vertegenwoordiging in belangrijke NIVRA-organen.

Op niet-vaktechnisch gebied waren er de problemen onder andere met betrekking tot waarneming bij een langdurige afwezigheid ten gevolge van ziekte of andere oorzaken. en de toenemende concurrentie op de markt van middenen kleinbedrijf door andere beroepsgroepen.

\section{Stuurgroep 'Kleine Kantoren'}

Een en ander is niet volledig aan het NIVRAbestuur voorbijgegaan.

In NIVRA-berichten van september 1971 verscheen een artikel van een ad hoc bestuurwerkgroep onder de titel Problematick van de kleine accountantskantoren.

Naar aanleiding van dit artikel en op initiatief van het NIVRA-bestuur kwam in 1972 een aantal vertegenwoordigers van de kleinere kintoren bij elkaar.

Zij waren bereid het initiatief te nemen tot het in het leven roepen van een 'Stuurgroep voor functionele gespreksgroepen van kleine kantoren ' die ten doel had het ondersteunen, profileren en het met elkaar in contact brengen van de leden uit de groep van de kleinere kantoren.

De Stuurgroep Kleine Kantoren was geboren en heeft een bestaan van negentien jaren gekend.

De Stuurgroep bestond uit periodiek wisselende leden, wairbij zo veel mogelijk getracht werd de verschillende regio's van ons land vertegenwoordigd te krijgen.

De Stuurgroep kwam regelmatig bij elkaar. waarbij in formele en soms informele sfeer lopende zaken. de kleinere kantoren betreffende, werden besproken en zonodig standpunten werden bepaald en doorgeleid naar het NIVRA-bestuur.

Periodiek werden de kleinere kantoren middels een nieuwsbrief van recente ontwikkelingen op de hoogte gebracht en eenmaal per jaar werd een
'Toogdag' gehouden, een bijeenkomst waarvoor alle kleinere kantoren werden uitgenodigd.

Op deze toogdag werd door de Stuurgroep verslag gedaan van de activiteiten in de voorbije periode en werd door het uitnodigen van gastsprekers informatie verstrekt ten aanzien van vaktechnische zaken of ontwikkelingen. die binnen het beroep speelden.

In de negentien jaar van haar bestaan heeft de

Stuurgroep belangrijke zaken weten te realiseren:

- een lid, afkomstig uit de kleinere kantoren. makt deel uit van het NIVRA-bestuur:

- in het overlegorgaan 'OPAK' werd een vaste vertegenwoordiging van de kleinere kintoren opgenomen:

- een waarnemingscontract werd op instigatie van de Stuurgroep door een kleine werkgroep van collegi's ontwikkeld:

- in de periode clat de honorering van de vrije beroepen ter discussie stond werden vertegenwoordigers van de kleine kantoren bij het overleg met overheidsinstanties betrokken.

In het begin van de jaren negentig heeft de Stuurgroep zich opgeheven en de vertegenwoordiging van de kleinere kantoren overgedragen aan de Vereniging SRA. destijds nog Samenwerkingsverband Registeraccountants.

\section{Totstandkoming en ontwikkeling van de Vereniging SRA}

Zoals onder 3 reeds werd iangegeven, heeft de Stuurgroep de eerste alanzet gegeven tot het behartigen van de belangen van de kleinere kantoren.

Echter de Stuurgroep was niet meer dan een gespreksplatform. waarbij beschikbaar komende informatie aan de leden kon worden geventileerd. Daarnaast zorgde de Stuurgroep voor de vertegenwoordiging in NIVRA-bestuur en 'OPAK'.

De contacien met de achterban waren echter beperkt; een achterban, die bovendien was samengesteld uit een groot aantal kantoren met een sterke diversiteit naar samenstelling. grootte. $k$ waliteit en doelstelling.

Het gevolg was, dat de door de vertegenwoordigers ingenomen standpunten weliswalar steeds vanuit de invalshoek van de kleinere kantoren werden bepaald maar niet met zekerheid kon worden gezegd dat dit het standpunt van de kleinere kantoren was. 
Verder beschikte de Stuurgroep niet over de financiële middelen om effectief ondersteuning aan de kleinere kantoren te kunnen geven.

Dit deed zich temeer voelen toen in de jaren tachtig de "kleinere kantoren" in toenemende mate met name door de grotere collega's op de kwaliteit van hun dienstverlening werden aangesproken.

De noodzaak voor ondersteuning op het kwalitatieve vlak deed zich sterk voelen, echter de financiële middelen waren hiervoor niet aanwezig.

Daarnaast voelden de kleinere kantoren zich in toenemende mate bedreigd door de agressieve wijze waarop met name de NOVAA de markt voor het midden- en kleinbedrijf aan het benaderen was en had men de indruk dat het NIVRA door haar multifunctioneel karakter niet of onvoldoende in staat was om de kleinere kantoren ondersteuning te geven, integendeel.

Men had veeleer het gevoel dat het belang van de kleinere kantoren werd opgeofferd in de onderhandelingen naar de NOVAA.

Dat deze onvrede met name bij de leden van de Stuurgroep leefde, zal geen verwondering wekken; zij werden immers regelmatig met de machteloosheid van de Stuurgroep geconfronteerd.

Het waren in eerste instantie dan ook leden en oud-leden van de Stuurgroep bij wie de mening post vatte, dat gestreefd moest worden naar een hechter en minder vrijblijvend samenwerkingsverband tussen de kleinere kantoren.

Dit samenwerkingsverband moest door een belangrijk en representatief deel van de groep kleinere kantoren worden gedragen. daarnaast een behoorlijk financieel draagvlak hebben en effectief aan belangenbehartiging van de kleine kantoren kunnen werken, dit alles zonder de zelfstandigheid van de kantoren aan te tasten; een vrijheid in gebondenheid.

De aard van de kleinere kantoren (beroepsbeoefenaren, die voor zich voor het vrije ondernemerschap hadden gekozen) maakte de uitkomst van deze poging op voorhand onzeker.

Bij de oprichtingsvergadering van 'SRA' op 23 november 1989 bleken echter voldoende leden overtuigd te zijn van en vertrouwen te hebben in de mogelijkheden van een dergelijk samenwerkingsverband: bij de oprichting hadden zich 48 kantoren gemeld, waarin 75 registeraccountants werkzaam waren.

De vereniging had zich de volgende doelen gesteld:
- maatregelen treffen ter zake van kwaliteitsbewaking in de beroepsuitoefening;

- verzorgen voortgezette educatie;

- verzorgen gezamenlijke reclame en voorlichting;

- verlenen van bijstand bij of het zelf ontwikkelen van software;

- afstemmen van en begeleiding in personeelsaangelegenheden;

- treffen van voorzieningen inzake beroepsaansprakelijkheid;

- onderhouden van contacten met derden alsmede participeren in overleg structuren;

- onderzoeken en realiseren van mogelijkheden voor internationale samenwerking;

- inspelen op ontwikkelingen binnen de Europese eenwording.

Voorwaar een ambitieus pakket.

Uitsluitend registeraccountants konden in persoon lid worden; daarnaast werd de omvang van de kantoren waar de deelnemende registeraccountants aan verbonden waren, beperkt tot die kantoren, waaraan niet meer dan 25 registeraccountants waren verbonden, zulks om het 'kleinekantorenkarakter' niet verloren te laten gaan.

Commissies werden ingesteld teneinde de terreinen te bewerken die in de doelstelling waren aangegeven en met grote voortvarendheid werden de activiteiten opgestart, waarbij 'educatie' en 'vaktechniek' bijna als vanzelfsprekend de trekkers waren.

$\mathrm{Na}$ een aarzelend begin waarbij een groot aantal kantoren nog even de kat uit de boom bleef kijken groeide de vereniging spectaculair.

Op dit moment zijn bijna 190 kantoren lid van SRA met daaraan verbonden 689 RA's en bijna 6000 personeelsleden.

Was het in eerste instantie nog het bestuur, dat tezamen met een beperkt secretariaat de werkzaamheden uitvoerde, al spoedig diende de noodzaak zich aan om meer permanent in de dagelijkse leiding te voorzien en werd een directeur aangetrokken waarnaast ook andere stafaanpassingen in kwaliteit en aantal hebben plaatsgevonden.

Ook het criterium voor het lidmaatschap moest worden aangepast; gebleken was dat een groot aantal leden binnen een kantoor op bestuursniveau samenwerkte met accountants-administratieconsulenten, hetgeen leidde tot een heroverweging van het lidmaatschapsvereiste resulterend in het 
vervangen van het persoonlijk lidmaatschap van een RA door een kantorenlidmaatschap.

Hierbij werd tevens de naam gewijzigd in SRA (Samenwerkingsverband van Registeraccountants en Accountant-Administratieconsulenten). SRA is hiermee van de specifieke belangenbehartiging van RA`s afgestapt en rekent nu de kantoren tot haar doelgroep. daarbij de belangen van de verschillende soorten beroepsbeoefenaren op één lijn zettend.

Op het gebied van de 'educatie' werd een omvangrijk cursussenpakket opgezet, dat algemeen waardering oogst.

Door de commissie vaktechniek werden een groot aantal activiteiten opgezet waarbij het SRAhandboek genoemd mag worden, een standaard handleiding met betrekking tot controlewerkzaamheden en diverse zaken, waarmee men binnen een kantoor geconfronteerd zou kunnen worden.

Ter bewaking van het kwaliteitsniveau werd tevens besloten tot het invoeren van een onderling review-systeem waarbij het handboek als leidraad zal dienen.

Ook ten aanzien van de andere doelstellingen zoals deze in de oprichtingsakte zijn vermeld werden belangrijke resultaten geboekt zoals bijvoorbeeld een gezamenlijke beroepsaansprakelijkheidsverzekering, internationale contacten, oprichting van een fiscale kring etc.

Samenvattend is SRA uitgegroeid tot een stabiele samenwerkingsvorm en tot een representatieve vertegenwoordiger van de kleine kantoren binnen het NIVRA, maar ook naar de NOVAA. Het aantal vertegenwoordigde beroepsbeoefenaren en de wijze waarop met kwaliteit van de uitoefening van het beroep ernst wordt gemaakt, maken de vereniging een serieus te nemen gesprekspartner naar beide beroepsorganisaties en in praktijk functioneert zij ook als zodanig gezien het beroep dat regelmatig wordt gedaan op haar inbreng.

\section{Samenvatting}

Door zich effectief te organiseren binnen SRA hebben de kleinere kantoren zich ontwikkeld tot een volwardige gesprekspartner binnen NIVRA en NOVAA.

Niet alle kleinere kantoren zijn lid van SRA; sommigen hebben zich om moverende redenen niet aangesloten en/of zijn andere samenwerkingsverbanden aangegaan.

Internationale samenwerking is hierbij regelmatig de overweging en niet zelden zijn deze kantoren tevens lid van SRA.

SRA heeft in ieder geval aangetoond dat het mogelijk is een groot aantal kantoren op een gemeenschappelijke basis te krijgen, met behoud van hun zelfstandigheid.

De toekomst zal leren hoe deze ontwikkeling zich doorzet; de tendens is een groeiend aandeel van de kleinere kantoren zoals uit de tabel op bijlage I blijkt.

Op de tabel op bijlage 1 is de ontwikkeling aangegeven van het aantal accountants dat werkzaam is in het openbare beroep, waarbij de jaren 1989/1990 en 1993/1994 naast elkaar gezet zijn.

Uit het overzicht blijkt. dat de 'kleinere accountantskantoren "een toenemend percentage van de in het openbare beroep werkzame accountants uitmaken ( $\operatorname{van} 23 \%$ in 1989 naar $31 \%$ in 1994). Tevens blijkt dat de absolute groei in 1994 bij de kleinere kantoren aanzienlijk hoger ligt dan bij de middelgrote en grote kantoren.

De verwachting is dat SRA van deze groei zijn deel zal meenemen en haar positie verder zal verstevigen in de komende jaren.

\section{Ten slotte}

Ook vanuit de kleinere kantoren past een gelukwens aan het NIVRA in het kader van haar eeuwfeest.

Ondanks alle hierboven beschreven perikelen, is het NIVRA ook voor deze groep steeds een Instituut van grote betekenis geweest en zal dat de komende jaren ongetwijfeld blijven.

\section{I T E R A T U U R}

Prof. Dr. A.J. Bindenga RA, (1982), Een toekomst voor de Nederlandse Accountancy, Tien jaar Stuurgroep kleine kantoren. Uitgave NIVRA 19 mei. 
Bijlage 1

\begin{tabular}{|c|c|c|c|c|c|c|c|c|c|}
\hline \multirow[t]{2}{*}{ Kantoren } & & \multirow[t]{2}{*}{1994} & \multicolumn{3}{|c|}{1993} & \multirow[t]{2}{*}{1990} & \multicolumn{3}{|c|}{1989} \\
\hline & & & in $\%$ & & in $\%$ & & in $\%$ & & in $\%$ \\
\hline 1 & RA & 479 & 71 & 428 & 69 & 335 & 70 & 304 & 74 \\
\hline 2 & RA's & 93 & 14 & 94 & 15 & 62 & 13 & 44 & 11 \\
\hline $3 / 5$ & RA's & 62 & 9 & 57 & 9 & 49 & 10 & 37 & 9 \\
\hline \multirow[t]{2}{*}{$6 / 10$} & RA's & 23 & 3 & 19 & 3 & 11 & 2 & 10 & 2 \\
\hline & & 657 & 97 & 598 & 96 & 457 & 96 & 395 & 96 \\
\hline $11 / 20$ & RA's & 8 & 1 & 10 & 2 & 8 & 2 & 5 & 1 \\
\hline $21 / 50$ & RA's & 4 & 1 & 5 & 1 & 5 & 1 & 5 & 1 \\
\hline $51 / 100$ & RA's & 3 & 0 & 2 & 0 & 1 & 0 & 2 & 0 \\
\hline \multirow[t]{2}{*}{100 of meer } & RA's & 5 & 1 & 5 & 1 & 5 & 1 & 5 & 1 \\
\hline & & 677 & 100 & 620 & 100 & 476 & 100 & 412 & 100 \\
\hline \multicolumn{10}{|c|}{ waarin werkzaam } \\
\hline 1 & $\mathrm{RA}$ & 479 & 14 & 428 & 13 & 335 & 12 & 304 & 12 \\
\hline 2 & RA's & 186 & 5 & 188 & 6 & 124 & 4 & 88 & 3 \\
\hline $3 / 5$ & RA's & 227 & 7 & 213 & 6 & 174 & 6 & 131 & 5 \\
\hline \multirow[t]{2}{*}{$6 / 10$} & RA's & 182 & 5 & 148 & 4 & 81 & 3 & 80 & 3 \\
\hline & & 1074 & 31 & 977 & 29 & 714 & 25 & 603 & 23 \\
\hline $11 / 20$ & RA's & 116 & 3 & 135 & 4 & 109 & 4 & 59 & 2 \\
\hline $21 / 50$ & RA's & 155 & 4 & 197 & 6 & 169 & 6 & 156 & 6 \\
\hline $51 / 100$ & RA's & 203 & 6 & 148 & 4 & 71 & 2 & 143 & 5 \\
\hline \multirow[t]{2}{*}{100 of meer } & RA's & 1942 & 56 & 1938 & 57 & 1822 & 63 & 1663 & 63 \\
\hline & & 3490 & 100 & 3395 & 100 & 2885 & 100 & 2624 & 100 \\
\hline
\end{tabular}

Bron: Jaarverslagen NIVRA 93/94 en 89/90 